Supporting Information

Amino Acids Labeled with $\left[{ }^{99 \mathrm{~m}} \mathrm{Tc}(\mathrm{CO})_{3}\right]^{+}$and Recognized by the L-Type Amino Acid Transporter LAT1

Yu Liu, JaeKyong Pak, Paul Schmutz, Matthias Bauwens, John Mertens, Hector Knight and Roger Alberto 


$$
\begin{aligned}
& \mathrm{Br} \chi_{\mathrm{n}} \mathrm{Br}+\overbrace{\mathrm{R}}^{\mathrm{NHAc}} \\
& \text { excess } \quad 4: \quad \mathrm{R}=-\mathrm{CN} \\
& \text { NaOEt } \downarrow \text { EtOH, reflux } \\
& \mathrm{Br} \psi_{\mathrm{n}}^{\mathrm{NHAC}}
\end{aligned}
$$

22: $\mathrm{R}=-\mathrm{COOEt} ; \mathrm{n}=2$

22a: $R=-C O O E t ; n=3$

22b: $\mathrm{R}=-\mathrm{COOEt} ; \mathrm{n}=4$

22c: $\mathrm{R}=-\mathrm{CN} ; \mathrm{n}=2$
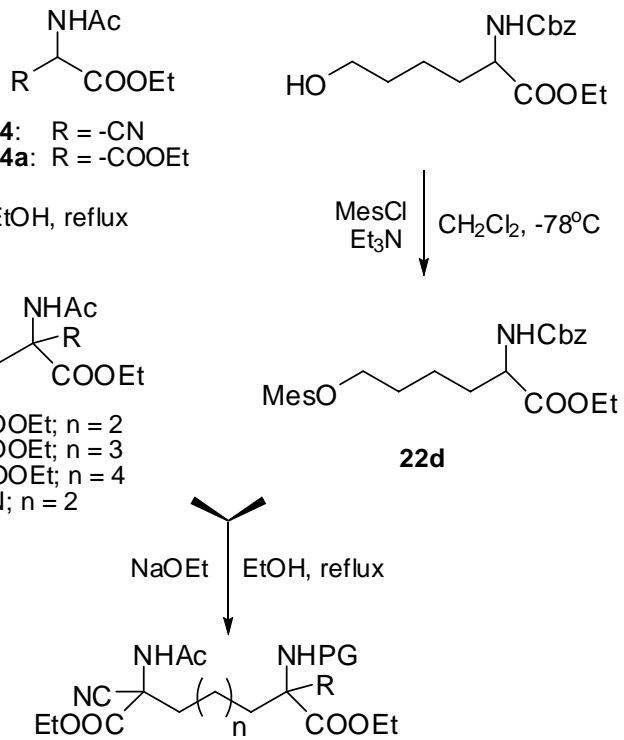

23: $\quad \mathrm{R}=-\mathrm{COOEt} ; \mathrm{n}=2 ; \mathrm{PG}=\mathrm{Ac}$

23a: $R=-C O O E t ; n=3 ; P G=A c$

23b: $R=-C O O E t ; n=4 ; P G=A c$

23d: $\mathrm{R}=-\mathrm{H} ; \mathrm{n}=2 ; \mathrm{PG}=\mathrm{Cbz}$
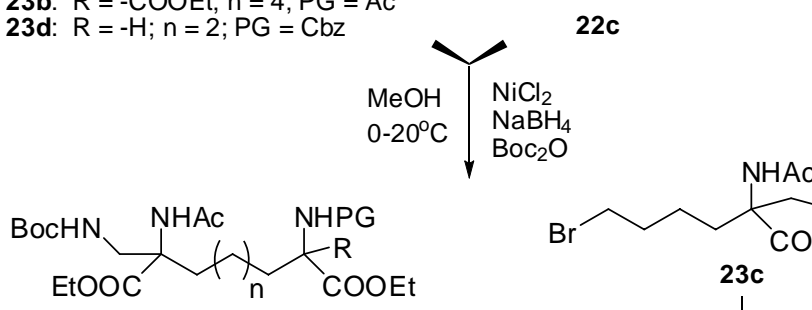

24: $\mathrm{R}=-$ COOEt; $\mathrm{n}=2 ; \mathrm{PG}=\mathrm{Ac}$

24a: $R=-C O O E t ; n=3 ; P G=A c$

24b: $R=-C O O E t ; n=4 ; P G=A c$

24d: $\mathrm{R}=-\mathrm{H} ; \mathrm{n}=2 ; \mathrm{PG}=\mathrm{Cbz}$
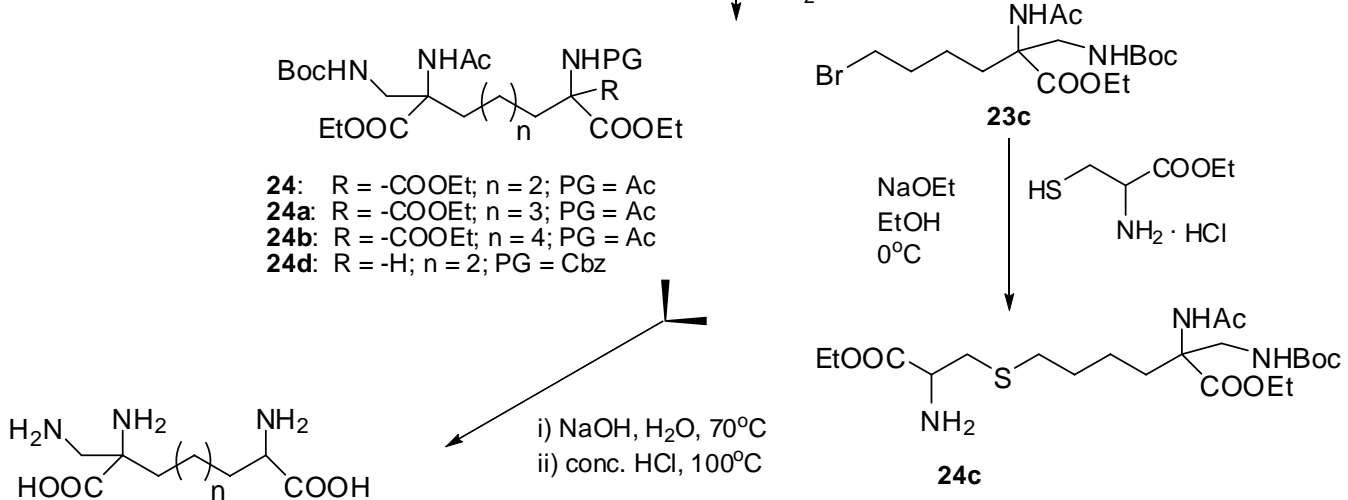

5: $\mathrm{n}=2$ (from 24d, L-form was obtained)

6: $n=3$

7: $n=4$

$\mathrm{NOCO}_{\mathrm{NH}_{2}}^{\mathrm{HOOC}} \overbrace{\mathrm{COOH}}^{\mathrm{NH}_{2}}$

25

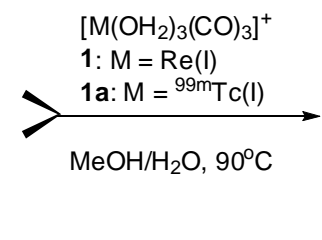

24c

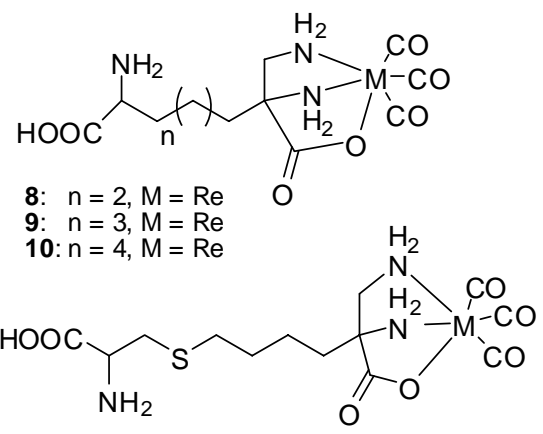

Scheme for overall transformations

\section{Common Abbreviations}

Ac<smiles>CC([13CH3])=O</smiles>

Cbz<smiles>CCC(=O)OCc1ccccc1</smiles>

Mes<smiles>CS(C)(=O)=O</smiles>

Boc

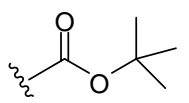




\section{Experimental procedure and analytical data.}

For D,L amino acid derivatives conjugated with diamino-propionic acid tripod (In scheme: $22 \rightarrow \mathbf{2 3} \rightarrow \mathbf{2 4}$ )

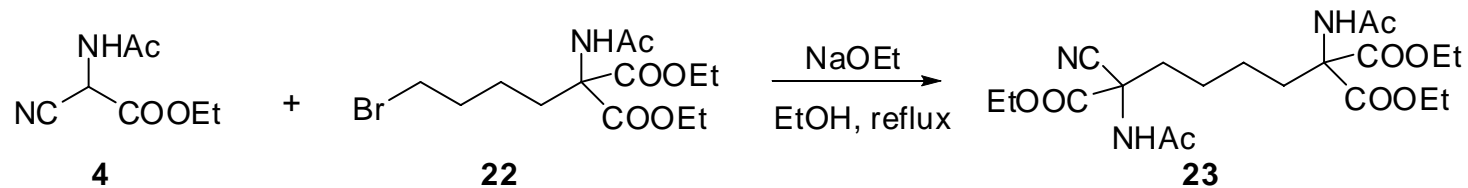

\section{Triethyl 1,6-diacetamido 6-cyanohexane 1,1,6-tricarboxylate (23)}

To a flask containing absolute ethanol $(20 \mathrm{~mL})$ was added sodium $(23 \mathrm{mg}, 1 \mathrm{mmol})$ with stirring. After complete dissolution of sodium ethyl acetamidocyanoacetate (4) $(170 \mathrm{mg}$, $1 \mathrm{mmol}$ ) was added and warmed up to $60^{\circ} \mathrm{C}$ for $30 \mathrm{~min}$. After cooling down to room temperature, $22(352 \mathrm{mg}, 1 \mathrm{mmol}){ }^{[1]}$ was added to the solution in one portion. The reaction mixture was refluxed overnight and then the solvent was removed under reduced pressure. The resulting residue was treated with $\mathrm{H}_{2} \mathrm{O}(20 \mathrm{~mL})$ and was extracted with EtOAc $(2 \times 50 \mathrm{~mL})$. The organic phase was washed with brine and dried over $\mathrm{MgSO}_{4}$. After filtration, the organic phase was evaporated to give a colorless oil, which was crystallized from EtOAc/Hexane to yield colorless crystals $(350 \mathrm{mg}, 79 \%$ )

${ }^{1} \mathrm{H}-\mathrm{NMR}\left(200 \mathrm{MHz}, \mathrm{CDCl}_{3}, \mathrm{ppm}\right) \delta 6.80(1 \mathrm{H}, \mathrm{NH}), 6.26(1 \mathrm{H}, \mathrm{NH}), 4.31(6 \mathrm{H},-$ $\left.\mathrm{OCH}_{2} \mathrm{CH}_{3}\right), 2.09\left(3 \mathrm{H}, \mathrm{COCH}_{3}\right), 2.06\left(3 \mathrm{H}, \mathrm{COCH}_{3}\right), 2.02-2.39(\mathrm{~m}, 4 \mathrm{H}), 1.20-1.51(\mathrm{~m}$, $13 \mathrm{H})$.

${ }^{13} \mathrm{C}$-NMR (125 MHz, $\mathrm{CDCl}_{3}$, ppm) $\delta 169.6$ (CO), 169.4 (CO), 168.3 (CO), 66.7, 62.9, 62.8, 33.6, 32.2, 23.5, 23.4, 23.3, $14.2\left(\mathrm{OCH}_{2} \mathrm{CH}_{3}\right), 14.1\left(\mathrm{OCH}_{2} \mathrm{CH}_{3}\right)$.

Anal. Calcd. for $\mathrm{C}_{20} \mathrm{H}_{31} \mathrm{~N}_{3} \mathrm{O}_{8}: \mathrm{C}, 54.41 ; \mathrm{H}, 7.08 ; \mathrm{N}, 9.52$. Found: C, 54.57; H, 7.02; N, $9.44 \%$.

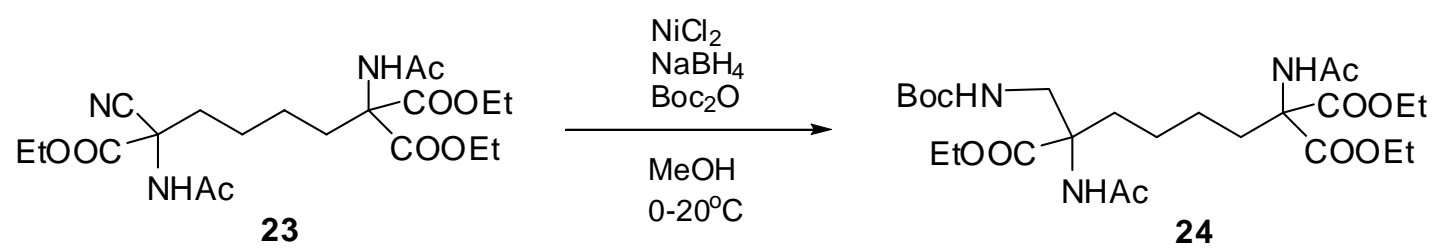

Triethyl 1,6-diacetamido 7-(tert-butoxycarbonylamino)heptane 1,1,6-tricarboxylate (24)

To the $\mathrm{MeOH}(10 \mathrm{~mL})$ solution of $23(220 \mathrm{mg}, 0.5 \mathrm{mmol})$ cooled with ice bath, was added (Boc) $)_{2} \mathrm{O}(218 \mathrm{mg}, 1 \mathrm{mmol})$ and $\mathrm{NiCl}_{2} \cdot 6 \mathrm{H}_{2} \mathrm{O}(12 \mathrm{mg}, 0.05 \mathrm{mmol})$ to give a green solution. To this solution was added $\mathrm{NaBH}_{4}(152 \mathrm{mg}, 4 \mathrm{mmol})$ in portions with stirring. The purple mixture was stirred overnight at $20^{\circ} \mathrm{C}$ and then diethylenetriamine $(0.06 \mathrm{~mL})$ was added. The reaction was stirred for $1 \mathrm{hr}$ before the volatile part of the mixture was removed by vacuum. The residue was partitioned between EtOAc and saturated $\mathrm{NaHCO}_{3}$ solution. The organic phase was dried with $\mathrm{MgSO}_{4}$. Removal of organic solvent gave a 
colorless residue, which was re-crystallized with EtOAc/Hexane to yield colorless crystals of $\mathbf{2 4}(200 \mathrm{mg}, 73 \%)$.

${ }^{1} \mathrm{H}-\mathrm{NMR}\left(500 \mathrm{MHz}, \mathrm{CDCl}_{3}, \mathrm{ppm}\right) \delta 6.74(\mathrm{~s}, 1 \mathrm{H}, \mathrm{NH}), 6.48(\mathrm{~s}, 1 \mathrm{H}, \mathrm{NH}), 4.83(\mathrm{~s}, 1 \mathrm{H}$, $\left.\mathrm{NHCOOC}\left(\mathrm{CH}_{3}\right)_{3}\right), 4.24\left(\mathrm{~m}, 6 \mathrm{H},-\mathrm{OCH}_{2} \mathrm{CH}_{3}\right), 3.85(1 \mathrm{H}$, Boc-NH-CHaHb- $), 3.62(1 \mathrm{H}$, BocNHCHaHb-), $2.05\left(3 \mathrm{H}, \mathrm{COCH}_{3}\right), 2.03\left(3 \mathrm{H}, \mathrm{COCH}_{3}\right), 1.75-2.29(\mathrm{~m}, 4 \mathrm{H}), 1.42(\mathrm{~s}, 9 \mathrm{H}$, $\left.\mathrm{C}\left(\mathrm{CH}_{3}\right)_{3}\right), 1.03-1.32(\mathrm{~m}, 13 \mathrm{H})$.

${ }^{13} \mathrm{C}-\mathrm{NMR}\left(125 \mathrm{MHz}, \mathrm{CDCl}_{3}\right.$, ppm) $\delta 172.7$ (CO), 169.9 (CO), 169.2 (CO), 168.3 (CO),

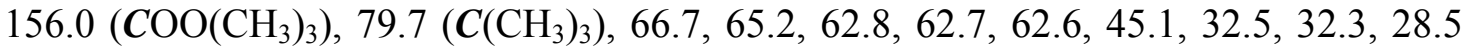
$\left(\mathrm{C}\left(\mathrm{CH}_{3}\right)_{3}\right), 24.3,24.0,23.9,23.3,14.3\left(-\mathrm{OCH}_{2} \mathrm{CH}_{3}\right), 14.2\left(-\mathrm{OCH}_{2} \mathrm{CH}_{3}\right)$.

Anal. Calcd. for $\mathrm{C}_{25} \mathrm{H}_{43} \mathrm{~N}_{3} \mathrm{O}_{10}$ : C, 55.03; H, 7.70; N, 7.94. Found: C, 55.21; H, 7.76; N, $7.99 \%$.

For preparation of $\operatorname{Re}$ compound $(8,9,10,20)$

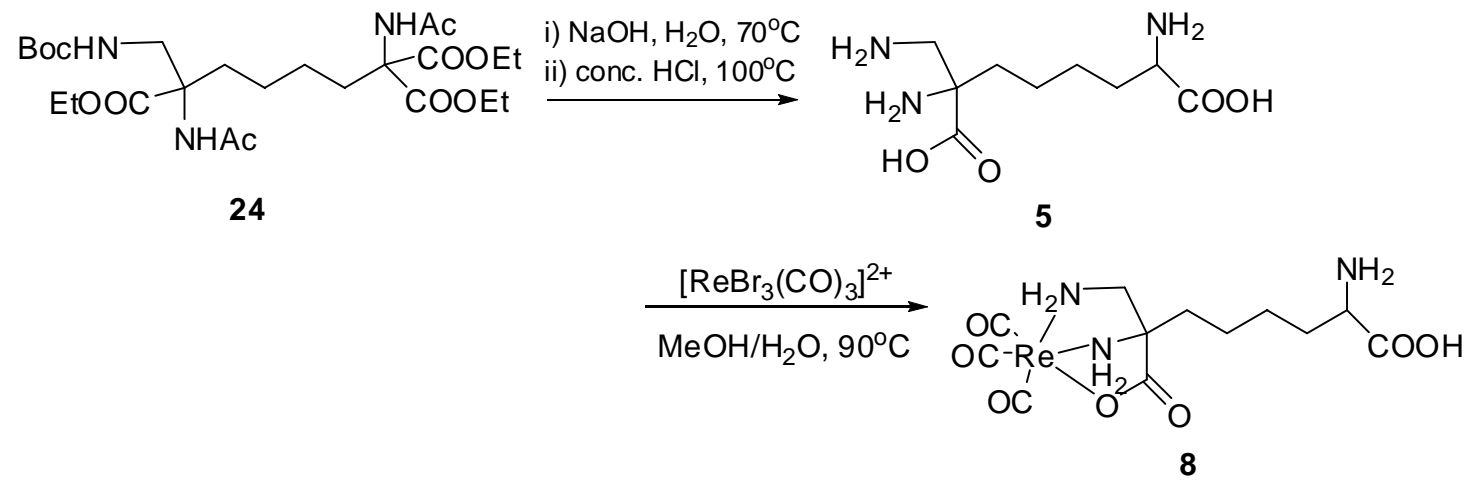

Preparation of $\left[\operatorname{Re}(5)(\mathrm{CO})_{3}\right](8)$

To the solution of $\mathrm{NaOH}\left(20 \mathrm{mg}\right.$ in $\left.3 \mathrm{~mL} \mathrm{H} \mathrm{H}_{2} \mathrm{O}\right)$ was added $24(110 \mathrm{mg}, 0.2 \mathrm{mmol})$ in $1 \mathrm{~mL} \mathrm{MeOH}$. The reaction mixture was stirred at $70^{\circ} \mathrm{C}$ overnight, and then $1 \mathrm{ml} \mathrm{HCl}$ (32\% wt) was added. The reaction mixture was refluxed overnight, cooled down to room temperature and washed with diethyl ether. The aqueous solution was neutralized to $\mathrm{pH} \sim$ 7 , and $40 \mathrm{mg}\left[\mathrm{Et}_{4} \mathrm{~N}\right]_{2}\left[\operatorname{Re}(\mathrm{CO})_{3} \mathrm{Br}_{3}\right](0.05 \mathrm{mmol})$ was added. The reaction mixture was heated at $70^{\circ} \mathrm{C}$ overnight and then water $/ \mathrm{MeOH}$ was removed. The residue was washed repeatedly with $\mathrm{CH}_{2} \mathrm{Cl}_{2}$. Column chromatography purification gave $\mathbf{8}$ as white solid. (19 $\mathrm{mg}, 74 \%$ calculated from $\left[\mathrm{Et}_{4} \mathrm{~N}\right]_{2}\left[\mathrm{Re}(\mathrm{CO})_{3} \mathrm{Br}_{3}\right]$ )

ESI-MS Calcd for $\mathrm{C}_{12} \mathrm{H}_{18} \mathrm{~N}_{3} \mathrm{O}_{7} \mathrm{Re}\left[\mathrm{M}^{+}\right]$: 503.07, found 503.73.

FT-IR (KBr, $\left.\mathrm{cm}^{-1}\right): 2019,1893,1642,1573,1410$.

HPLC trace is shown in Figure 1.

The same method was also used for $\mathbf{9 , 1 0}$ and 20. 
For L-amino acid derivatives conjugated with diamino-propionic acid tripod

(in Scheme: $22 d \rightarrow 23 d \rightarrow 24 d$ and $23 c \rightarrow 24 c$ )<smiles>CCOC(=O)C(CCCCO)NC(=O)OCc1ccccc1</smiles>

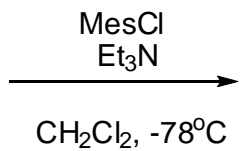<smiles>CCOC(=O)C(CCCCOC)NC(=O)OC</smiles>

22d

(S)-2-Benzyloxycarbonylamino 6-methanesulfonyloxy-hexanoic acid ethyl ester (22d)

(S)-2-Benzyloxycarbonylamino-6-hydroxy-hexanoic acid ethyl ester (804 mg, $2.6 \mathrm{mmol})$

${ }^{[2]}$ and methanesulfonylchloride $(0.222 \mathrm{ml}, 2.86 \mathrm{mmol})$ were dissolved in $5 \mathrm{ml} \mathrm{CH} \mathrm{Cl}_{2}$ and cooled to $-78^{\circ} \mathrm{C}$ under nitrogen. Triethylamine $(0.38 \mathrm{ml}, 2.86 \mathrm{mmol})$ was added dropwise to the stirred solution at $-78^{\circ} \mathrm{C}$. The solution was then allowed to warm up to room temperature and stirred during $2 \mathrm{~h}$. The reaction mixture was then diluted by $5 \mathrm{ml}$ $\mathrm{CH}_{2} \mathrm{Cl}_{2}$ and washed with water and brine. The organic phase was dried with $\mathrm{Na}_{2} \mathrm{SO}_{4}$ and evaporated under reduced pressure. The product was obtained as a yellow oil $(962 \mathrm{mg}$, $96 \%$ ).

${ }^{1} \mathrm{H}$ NMR (500 MHz, $\left.\mathrm{CDCl}_{3}, \mathrm{ppm}\right): \delta 7.36(\mathrm{~m}, 5 \mathrm{H}, \mathrm{Ar}), 5.45(1 \mathrm{H}, \mathrm{NH}), 5.11\left(\mathrm{~s}, 2 \mathrm{H}, \mathrm{CH}_{2-}\right.$ Ar), $4.37(\mathrm{~m}, 1 \mathrm{H}), 4.20(\mathrm{~m}, 4 \mathrm{H}), 2.99\left(\mathrm{~s}, \mathrm{CH}_{3}, 3 \mathrm{H}\right), 2.10-1.40(\mathrm{~m}, 6 \mathrm{H}), 1.29(\mathrm{t}, J=7.1 \mathrm{~Hz}$, $\left.-\mathrm{CH}_{2} \mathrm{CH}_{3}\right)$.

${ }^{13} \mathrm{C}-\mathrm{NMR}\left(125 \mathrm{MHz}, \mathrm{CDCl}_{3}, \mathrm{ppm}\right): \delta 172.3$ (CO), 156.1 (NCO), 136.4 (Ar), 128.7 (Ar), 128.4(Ar), 128.3(Ar), 69.6, 67.2, 61.8, 53.7, 37.5, 32.3, 28.8, 21.4, 14.4.<smiles>CCOC(=O)NC(C#N)C(=O)OCC</smiles>

4<smiles>CCOC(=O)C(CCCCOC(C)=O)NC(=O)OC</smiles>

22d

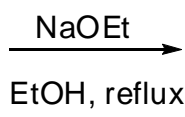

EtOH, reflux<smiles>CCOC(=O)NC(CCCCC(C)(N)OC(C)=O)C(=O)OCC</smiles>

23d

Diethyl 2-acetamido-7-(benzyloxycarbonylamino)-2-cyanooctanedioate (23d)

23d was obtained by the same coupling condition as that for $\mathbf{2 3}$ but that of purification method. The resulting mixture, after evaporation of solvent $(\mathrm{EtOH})$, was loaded on silica gel and then purified with EtOAc/Hexane gradient by chromatography. The product of 23d was obtained as a very pale yellow oil.

${ }^{1} \mathrm{H}$ NMR (300 MHz, $\left.\mathrm{CDCl}_{3}, \mathrm{ppm}\right): \delta 7.38(\mathrm{~m}, 5 \mathrm{H}, \mathrm{Ar}), 6.30(1 \mathrm{H}, \mathrm{NH}), 5.40(1 \mathrm{H}, \mathrm{NH})$ 5.14 (s, 2H, CH -Ar), 4.20-4.37 (m, 5H), 2.10 (s, 3H, COCH $\left.\mathbf{H}_{3}\right), 2.30-1.40(\mathrm{~m}, 8 \mathrm{H}), 1.30$ $\left(\mathrm{m}, 6 \mathrm{H},-\mathrm{CH}_{2} \mathrm{CH}_{3}\right)$.

Anal. Calcd. for $\mathrm{C}_{23} \mathrm{H}_{31} \mathrm{~N}_{3} \mathrm{O}_{7}:$ C, 59.86; H, 6.77; N, 9.10. Found: C, 60.03; H, 6.84; N, $9.16 \%$. 
<smiles>CCOC(=O)NC(CCCCC(C#N)(NC(C)=O)NC(C)=O)C(=O)OCC</smiles>

23d

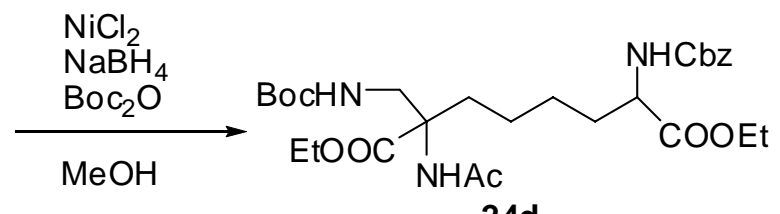

24d

Diethyl 10-acetamido 15,15-dimethyl 3,13-dioxo 1-phenyl 2,14-dioxa 4,12diazahexadecane 5,10-dicarboxylate (24d)

$\mathbf{2 4 d}$ was obtained by the same reduction condition as that for $\mathbf{2 4}$ till the last step. Instead of recrystallization method, the residue was loaded on silica gel and purified with

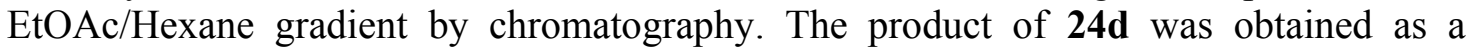
colorless oil.

${ }^{1} \mathrm{H}$ NMR (300 MHz, $\left.\mathrm{CDCl}_{3}\right): \delta 7.38(\mathrm{~m}, 5 \mathrm{H}, \mathrm{Ar}), 6.30(1 \mathrm{H}, \mathrm{NH}), 5.40(1 \mathrm{H}, \mathrm{NH}) 5.14(\mathrm{~s}$, 2H, $\mathrm{CH}_{2}$-Ar), $4.87(1 \mathrm{H}, \mathrm{NH}), 4.20-4.37$ (m, 5H), $3.86(1 \mathrm{H}, \mathrm{Boc}-\mathrm{NH}-\mathrm{CHaHb}-), 3.62(1 \mathrm{H}$, BocNHCHaHb-), 2.07 (3H, COCH $), 1.42$ (s, 9H, C(CH CH$\left._{3}\right), 1.50-1.03$ (m, 14H).

Anal. Calcd. for $\mathrm{C}_{28} \mathrm{H}_{43} \mathrm{~N}_{3} \mathrm{O}_{9}$ : C, 59.45; H, 7.66; N, 7.43. Found: C, 59.63; H, 7.72; N, $7.50 \%$.<smiles>CCOC(=O)NC(C)(CCCCBr)C(=O)OCC</smiles>

23c

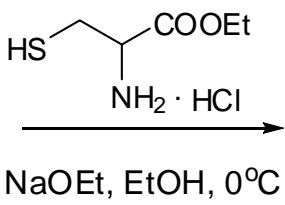

$\mathrm{NaOEt}, \mathrm{EtOH}, 0^{\circ} \mathrm{C}$<smiles>CCOC(=O)C(N)CSCCCCC(N)(C(=O)OCC)C(=O)OCC</smiles>

24c

Preparation of 24c

To the solution of NaOEt (1.40 mg, $2 \mathrm{mmol})$ in EtOH ( $5 \mathrm{ml})$, was added L-Cysteine ethyl ester hydrochloride $(185 \mathrm{mg}, 1 \mathrm{mmol})$ at $0^{\circ} \mathrm{C}$. After the mixture stirring for $2 \mathrm{~min}$, XII (410 mg, $1 \mathrm{mmol}$ ) in $2 \mathrm{ml} \mathrm{EtOH}$ was added to it. The resulting mixture was stirred for 30 min and then the reaction was quenched with water. The reaction mixture was extracted with EtOAc. The organic solution was washed with brine and dried with $\mathrm{MgSO}_{4}$. XIII was obtained by chromatography as a colorless oil. Yield $130 \mathrm{mg}, 27 \%$.

${ }^{1} \mathrm{H}$ NMR $\left(300 \mathrm{MHz}, \mathrm{CDCl}_{3}\right), \delta 6.42(1 \mathrm{H}, \mathrm{NH}), 4.80(2 \mathrm{H}, \mathrm{NH}), 4.02(1 \mathrm{H}, \alpha-\mathrm{CH}), 4.27$ $\left(4 \mathrm{H}, \mathrm{OCH}_{2}\right), 2.90-2.50\left(4 \mathrm{H}, \mathrm{CH}_{2} \mathrm{SCH}_{2}\right), 2.04(3 \mathrm{H}, \mathrm{s}, \mathrm{COCH}), 1.90-1.50(\mathrm{~m}, 4 \mathrm{H}), 1.41$ (s, $\left.9 \mathrm{H}, \mathrm{C}\left(\mathrm{CH}_{3}\right)_{3}\right)$ 1.05-1.32(m, 8H)

\section{Labelling of $\left[{ }^{99 \mathrm{~m}} \mathrm{Tc}(\mathrm{CO})_{3}\left(\mathrm{H}_{2} \mathrm{O}\right)_{3}\right]^{+}(1 \mathrm{a})$}

$\mathrm{Na}\left[{ }^{99 \mathrm{~m}} \mathrm{TcO}_{4}\right]$ - was eluted from a ${ }^{99} \mathrm{Mo} /{ }^{99 \mathrm{~m}} \mathrm{Tc}$ generator. The precursor $1 \mathbf{a}$ was prepared by literature method ${ }^{[3]}$. The technetium complexes were prepared in aqueous solution of the ligands $\left(10^{-3}-10^{-5} \mathrm{M}\right.$, PP buffer $\left.\mathrm{pH} \sim 7.4\right)$. The complex was analysed by HPLC coupled with $\gamma$ detector. HPLC traces of ${ }^{99 \mathrm{~m}} \mathrm{Tc}-\mathrm{aa}^{4}$ and ${ }^{99 \mathrm{~m}} \mathrm{Tc}-\mathrm{aa}^{5}$ were shown in Figure 2 and 3. 


\section{HPLC Condition}

C-18 Column: Machery-Nagel ET 250/3 Nucleosl 120-5

Mobile phase: A, $0.1 \%$ TFA; B, $\mathrm{MeOH}$

Gradient:

0-3 $\min , 100 \% \mathrm{~A}$

3-3.1 min, 0 to $25 \% \mathrm{~B}$

$3.1-9 \mathrm{~min}, 25 \% \mathrm{~B}$

9-9.1 $\mathrm{min}, 25 \% \mathrm{~B}$ to $34 \% \mathrm{~B}$

9.1-20 $\min , 34 \%$ B to $100 \% \mathrm{~B}$

$20-25 \mathrm{~min}, 100 \% \mathrm{~B}$

$25-25.1 \mathrm{~min} 100 \% \mathrm{~B}$ to $100 \% \mathrm{~A}$

$25.1-30 \min 100 \% \mathrm{~A}$

\section{Reference}

[1] V. V. Ragulin, M. E. Bofanova, E. N. Tsvetkov, Bull. Acad. Sci. USSR Div. Chem.Sci. (Engl.Transl.), 1989, 2377-2382.

[2] A. K. Bence, P. A. Crooks, Synthetic Communications, 2003, 32, 2075-2082.

[3] R. Alberto, R. Schibli, R. Waibel, U. Abram, A. P. Schubiger, Coord. Chem. Rev., 1999, 190-192, 901-919.

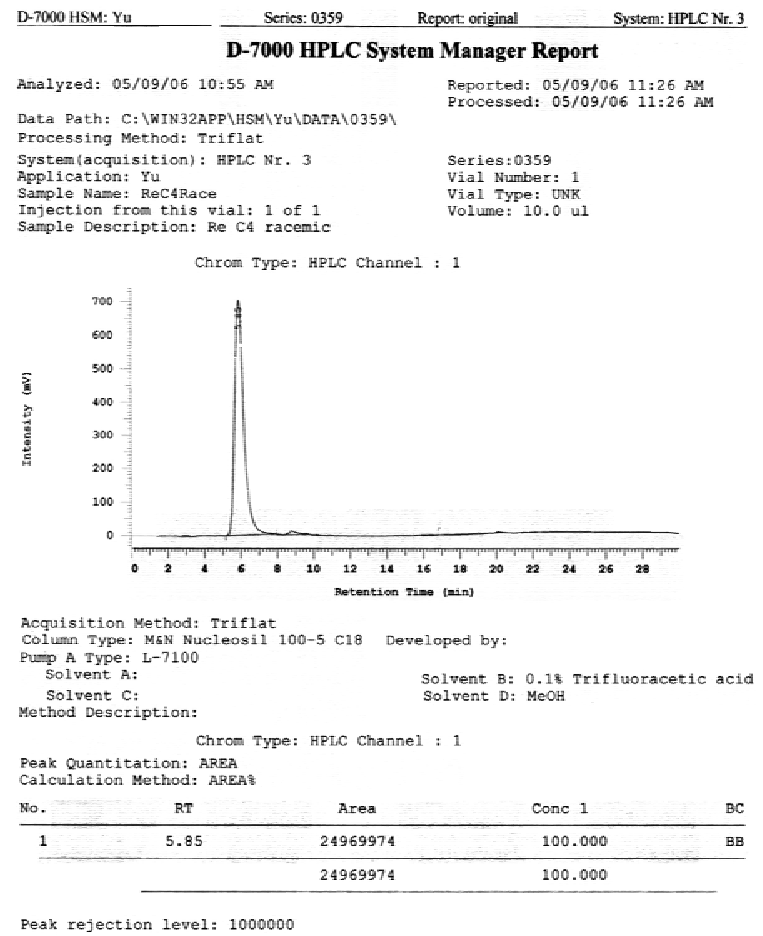

Figure 1. HPLC trace of Re-aa ${ }^{4}$ 


\section{Determination of $\mathrm{Ki}$ and efflux for $\mathrm{Re}-\mathrm{aa}^{4}$}

R1M rhabdomyosarcoma cells (VUB) were cultivated in cell culture flasks (NUNC) at 37 ${ }^{\circ} \mathrm{C}$ and a $5 \% \mathrm{CO}_{2}$ atmosphere in MEM (Minimum Essential Medium with Earl's salts and with L-glutamine) (Invitrogen) in the presence of $10 \%(\mathrm{v} / \mathrm{v})$ Foetal Bovine Serum (FBS) (Invitrogen), $100 \mathrm{IU} / \mathrm{mL}$ Penicilline (Invitrogen) and $100 \mu \mathrm{g} / \mathrm{mL}$ Streptomycine (Invitrogen). For in vitro experiments cells were cultivated in 6-well-plates (NUNC) for 2 days until adhesive mono-layers, containing about $4( \pm 0.2)$ million cells per well were obtained.

In vitro experiments were carried out in 6-well-plates (VWR), using at least three wells for each data-point. Cells were counted by means of a Bürker counting chamber. Influx and efflux were studied a $\mathrm{Na}^{+}$free buffer (HEPES- buffer: $\mathrm{pH} 7,4 ; 100 \mathrm{mM}$ Choline-Cl

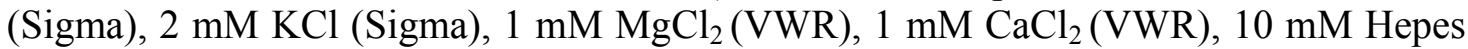
(Sigma), $5 \mathrm{mM}$ Tris (VWR), $1 \mathrm{~g} / 1$ glucose (VWR) and $1 \mathrm{~g} / 1$ Bovine Serum Albumin (Sigma)). The process was terminated by physical withdrawal of the buffer and washing three times with ice-cold phosphate-buffered saline (PBS). Subsequently, the cells were detached from the well with $2 \mathrm{ml}$ of $0,1 \mathrm{M} \mathrm{NaOH}$ (VWR) and transferred to Economy glass vials (Perkin Elmer), at which point $20 \mathrm{ml}$ scintillation liquid (Ultima Flo AP, Canberra) was added and mixed. The amount of radioactivity in the vials was measured using a Berthold BF 5020 scintillation counter (Berthold) (0-450 mV window).

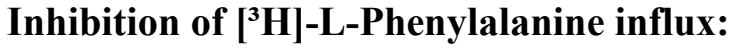

In these inhibition experiments the cells were incubated with $37 \mathrm{kBq}\left[{ }^{3} \mathrm{H}\right]-\mathrm{L}-\mathrm{Phe}$ for 1 minute in HEPES- buffer supplemented with substrate concentrations varying from 0.01 to $0.2 \mathrm{mM}$ L-Phe and $0.1 \mathrm{mM}$ "inhibitor".

Lineweaver-Burk plots were used to study the type of inhibition of the inhibitors from their inhibition potential of the $\left[{ }^{3} \mathrm{H}\right]-\mathrm{L}-\mathrm{Phe} / \mathrm{L}-\mathrm{Phe}$ couple. The apparent $\mathrm{Km}$ and corresponding $\mathrm{Ki}$ values were calculated by means of Eadie-Hofstee plots and Lineweaver-Burk plots. The formula used to calculate the $\mathrm{Ki}$ is: $K i=[I] /\left(\left(K m_{a p p} / K m\right)-1\right)$ where $[\mathrm{I}]$ is the inhibitor concentration, $\mathrm{Km}$ is the MichaelisMenten constant of the substrate $\left(\left[{ }^{3} \mathrm{H}\right]-\mathrm{L}-\mathrm{Ph} / \mathrm{L}-\mathrm{Phe}\right)$ and $\mathrm{Km}_{\text {app }}$ is the apparent value of $\mathrm{Km}$ for substrate transport in the presence of the inhibitor.

\section{Trans-stimulation of $\left[{ }^{3} \mathrm{H}\right]-\mathrm{L}-\mathrm{Phenylalanine}$ efflux:}

The cells were incubated with $37 \mathrm{kBq}\left[{ }^{3} \mathrm{H}\right]-\mathrm{L}-\mathrm{Phe}$ for 15 minutes in HEPES- buffer supplemented with $0.1 \mathrm{mM}$ L-Phe. The incubation medium was removed and the cells were washed three times with ice-cold PBS. Subsequently, the cells were incubated for 1 minute with a HEPES- buffer containing $0.1 \mathrm{mM}$ inhibitor. This medium was removed and the cells were washed three times with ice-cold PBS, detached with $0.1 \mathrm{M} \mathrm{NaOH}$, suspended and transferred to Economy glass vials (Perkin Elmer), at which point $20 \mathrm{ml}$ scintillation liquid (Ultima Flo AP, Canberra) was added and mixed. The amount of radioactivity in the vials was measured using a Berthold BF 5020 scintillation counter (Berthold) (0-450 $\mathrm{mV}$ window). The efflux is expressed as the percentage of radioactivity that was displaced out of the cells by the inhibitor to the radioactivity that was in the cells at the start of the efflux experiment. 


\begin{tabular}{|l|r|}
\multicolumn{2}{|c}{ Ki $(\mu \mathrm{M})$} \\
\hline L-Cys-S-BZL & 14 \\
\hline L-Cys-S-Bu & 15.8 \\
\hline L-Leu & 28 \\
\hline L-2-I-Phe & 35 \\
\hline L-Phe (ki) & 47 \\
\hline D-2-I-Phe & 50 \\
\hline L-Phe (km) & 51 \\
\hline L-FMP & 55 \\
\hline Cp-AA & 60 \\
\hline L-Ile & 76 \\
\hline L-Methionine & 106 \\
\hline L-Cys-S-Me & 112 \\
\hline Cp-S-AA & 137 \\
\hline BCH & 153 \\
\hline L-Lysine-OH & 232 \\
\hline C4-Re-DAAM (L, pure) & 308 \\
\hline D-Leu & 365 \\
\hline L-Cysteine & 390 \\
\hline L-Cys-SCH2C(CH3)3*HCL & 481 \\
\hline C4-Cys-Re-DAAM (L, pure) & 806 \\
\hline D-Ile & 872 \\
\hline C6-Re-DAAM & 1100 \\
\hline C4-Re-DAAM (D,L pure) & 2200 \\
\hline C4-Re-DAAM (D,L unpure) & 4500 \\
\hline C5-Re-DAAM & 5300 \\
\hline C7-Re-DAAM & \\
\hline C4-sideon-Re-DAAM & \\
\hline L-Lysine & \\
\hline & \\
\hline
\end{tabular}

\begin{tabular}{|r|} 
Efflux (\%) \\
\hline 32 \\
\hline 36 \\
\hline 37.0 \\
\hline 45.0 \\
\hline 32 \\
\hline 21.0 \\
\hline 32 \\
\hline 21.1 \\
\hline 24.6 \\
\hline 27.0 \\
\hline 30 \\
\hline 21 \\
\hline 8 \\
\hline 24 \\
\hline 16.1 \\
\hline 12.3 \\
\hline 8.3 \\
\hline 11 \\
\hline 9.5 \\
\hline 6.5 \\
\hline 13.4 \\
\hline 14.9 \\
\hline 10.6 \\
\hline 10.2 \\
\hline 9.3 \\
\hline 0.0 \\
\hline 0.0 \\
\hline 1.1 \\
\hline
\end{tabular} 
Efflux and Ki-value of all compounds

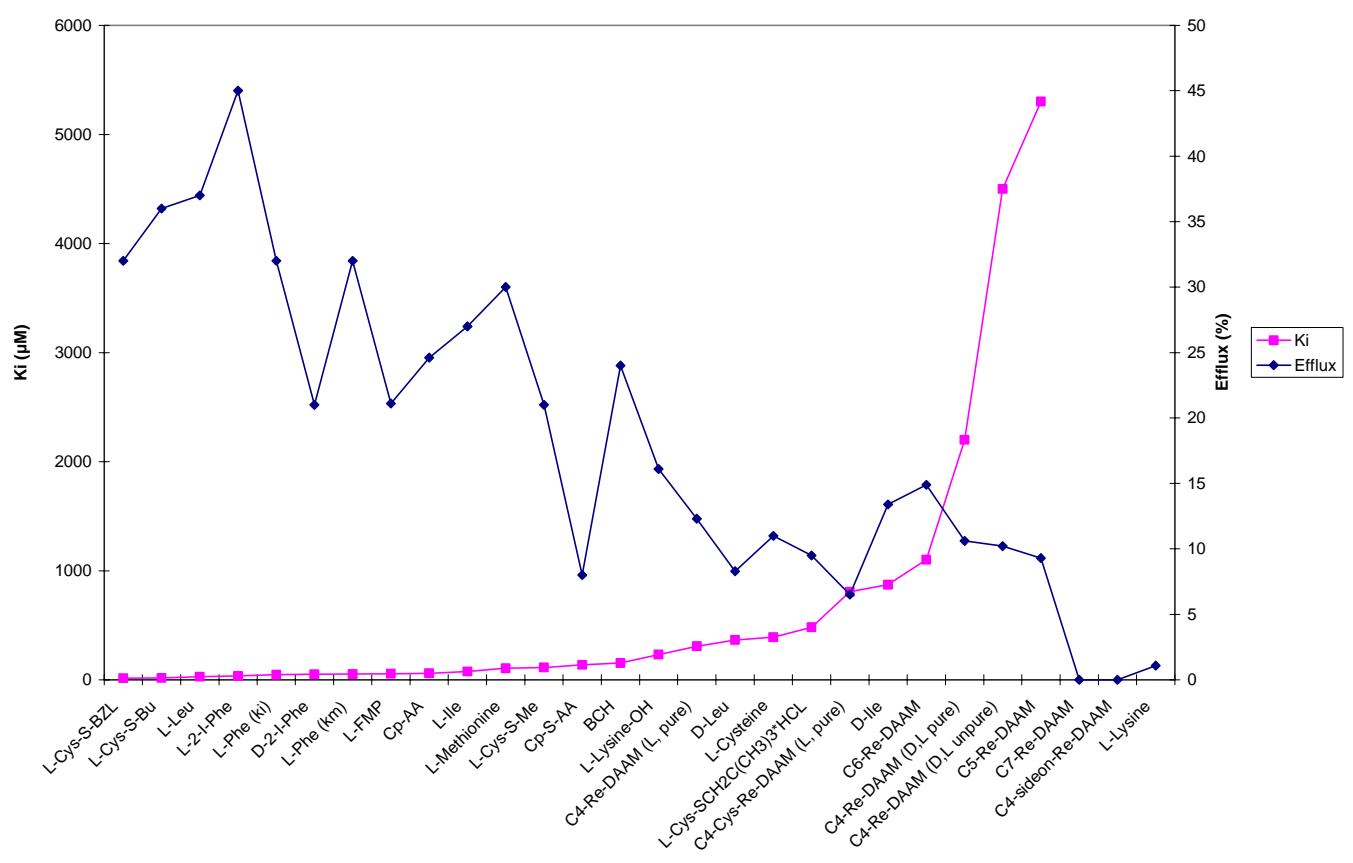

